Nowoczesne Systemy Zarządzania

Zeszyt 16 (2021), nr 1 (styczeń-marzec)

ISSN 1896-9380, s. 49-70

DOI: $10.37055 /$ nsz/133888

Modern Management Systems

Volume 16 (2021), No. 1 (January-March)

ISSN 1896-9380, pp. 49-70

DOI: $10.37055 / \mathrm{nsz} / 133888$
Instytut Organizacji i Zarządzania Wydział Bezpieczeństwa, Logistyki i Zarządzania

Wojskowa Akademia Techniczna

w Warszawie

Institute of Organization and Management Faculty of Security, Logistics and Management Military University of Technology in Warsaw

\title{
The effects of ICTs' application in enterprises on the NewConnect market
}

\section{Skutki zastosowania ICT w przedsiębiorstwach z rynku NewConnect}

\author{
Jacek Woźniak \\ Military University of Technology, \\ Faculty of Security, Logistics and Management \\ jacekj.wozniak@wat.edu.pl; ORCID: 0000-0001-7592-010 \\ Paweł Wereda \\ Polish producer of cutting tools FENES S.A. in Siedlce \\ weredapawel@tlen.pl; ORCID: 0000-0001-9347-7294
}

\begin{abstract}
The subject of the analyses carried out is the use of ICTs by enterprises listed on the NewConnect market. The aim of the article is to identify the basic effects of the use of ICTs in Polish enterprises carrying out innovative activities (listed on the NewConnect market). The study used the CASI technique (a sample of 60 innovative enterprises). The study used methods such as: analysis, synthesis, deduction and induction. Keywords: ICTs, NewConnect, enterprise, innovativeness

Abstrakt. Przedmiotem przeprowadzonych analiz jest stosowanie technologii teleinformatycznych przez przedsiębiorstwa notowane na rynku NewConnect. Celem artykułu jest identyfikacja podstawowych efektów stosowania ICT w polskich przedsiębiorstwach prowadzących działalność innowacyjną (notowanych na rynku NewConnect). W badaniu wykorzystano technikę CASI (badanie na próbie 60 innowacyjnych przedsiębiorstw). Zastosowano metody: analizy, syntezy, dedukcji oraz indukcji.
\end{abstract}

Słowa kluczowe: ICT, NewConnect, przedsiębiorstwo, innowacyjność 


\section{Introduction}

The scale and scope of application of ICT in modern enterprises should result from changes in the environment, which in turn may determine transformations within enterprises. One of the basic phenomena that affects both the implementation of ICT and the effects of using ICT in enterprises is the globalization of management and socio-cultural processes (Oleksyn, 2013, p. 307 et seq.; Woźniak, Pawlak, Zaskórski, 2018, p. 55). ICT are becoming an integral part of people's lives practically all over the world, supporting the activities of both individuals and entire communities (including enterprises). It can even be assumed that some aspects of people's life and work cannot be effectively implemented without the use of specific ICT technologies. Examples include the processes of verbal communication over long distances and data transmission. Thus, ICT technologies constitute a specific "core" and "catalyst" for the implementation of management processes (referring to both business and information-decision-making processes). It is worth emphasizing here that the use of ICT creates quite obvious business effects (lowering costs, increasing efficiency, shortening the time of process implementation, etc.). On the other hand, the effects referring to the improvement of information and decision-making processes are less predictable. Therefore, this article will focus on this group of effects of using ICT in enterprises. At this point, it can be noted that ICT can be the basis for creating a number of benefits for modern enterprises, relating to, inter alia, the areas of: processing information resources, using information resources in the company's operations, expanding the system of acquiring information resources, improving the knowledge management system, or increasing the efficiency of communication processes with stakeholders.

The aim of the article is to identify the basic effects of using ICT in Polish enterprises conducting innovative activity (listed on the NewConnect market). On the other hand, the subject of empirical research is the use of ICT technologies by enterprises listed on the NewConnect market. The CASI technique was used as part of the empirical study. The survey was conducted on a sample of 60 innovative companies listed on the NewConnect market. Moreover, the following methods were used in the study: analysis, synthesis, deduction and induction.

The article consists of five main parts, dealing in turn with the issues: (1) the identification of general effects of using ICT in enterprises, (2) the specificity of the NewConnect market, (3) the methodology of empirical research, (4) the analysis of the results of the empirical research, and (5) requests. 


\section{General effects of ICTs' application in enterprises}

In the conditions of the modern world, as well as the intensifying processes of globalization, the development of ICT may be responsible for causing a strong and positive synergy effect - resulting, among others, from the integration of tangible and intangible assets - mainly in the context of supporting the implementation of processes in the enterprise, both in the material and financial sphere, as well as in the intellectual sphere (know-how, knowledge, innovation, etc.) (see Korpus, 2016). It is also worth mentioning here the creation of interactions between the local and global scale of the company's operations - it is related to establishing cooperation with various classes of stakeholders who have diversified and geographically diversified resources. It is also important for the company to consciously shape relations with external entities and to jointly create information resources (Nowicka, 2016; Woźniak, Pawlak, Zaskórski, 2018, pp. 66-67).

At this point, it should be clearly emphasized that ICT should correspond with the integration and organizational process and formal consistency of entities cooperating with a given enterprise. One should bear in mind the transition of enterprises from the so-called "static" systems for "flexible" and "intelligent" configurations (see Wereda, Woźniak, 2017). The point here is for the enterprise to "harmonize" with the immediate environment and partners (e.g. business), and not overly invest in ICT (Orzechowski, 2008, p. 61 et seq.). A situation when an enterprise decides to limit and simplify the applied IT solutions is not synonymous with lowering its information and decision-making potential. For example, the fact that spreadsheets are the basis for collecting, analyzing and archiving operational data in an enterprise is not the same as the fact that this enterprise does not benefit from technological "news". Spreadsheets can be archived and made available to cooperators using cloud computing, or advanced methods of data mining can be used in spreadsheets (see Larose, 2006; Nowicka, 2014; Gapinski, 2016; Krok, 2016; Krok, 2017; Woźniak, Pawlak, Zaskórski, 2018, pp. 57-58).

Nowadays, in the context of the development of innovative enterprises, the Internet technology is of particular importance, as it enables enterprises with a "limited" portfolio of IT solutions to be used to implement processes on a global scale. It is the basis for creating, among others, virtual structures. This is of key importance for the formation and development of the so-called sharing economy, where the company's potential is not mainly determined by access to specific resources (not only material and financial, but also information), but rather innovation and the ability to communicate and process resources (see Rynio, 2010; AdamskaChudzińska, 2014). 
The use of ICT in modern enterprises can therefore work as (Woźniak, Pawlak, Zaskórski, 2018, p. 63):

- shaping the key sources of competitive advantage - by creating and diffusing useful knowledge (see Skrzypek, 2014b, p. 8 et seq.);

- modification of the organizational structure - as a result of establishing the principles of information asymmetry (Zaskórski, 2012), increasing the speed of decision-making processes and flexibility of the enterprise, or introducing changes towards heterarchy (Mrówka, 2013, pp. 67 et seq.; Grudzewski et al., 2010, pp. 288 et seq.);

- increasing the scope and improving the competences of the managerial staff - including in terms of analytical and decision-making skills, as well as the operation and constructive use of specific IT systems and IT tools (based on: Szmajser, 2018, p. 93 et seq.);

- improving the exchange of information resources within the company and with external stakeholders, as well as communicating specific issues to the environment (e.g. as part of PR activity) (see Żur, 2005, pp. 148 et seq.; Sarnecka, 2006, pp. 154 et seq.; Ziółkowska, Karbownik, 2018, pp. 544 et seq.; Korzyński, 2018, pp. 158 et seq.);

- searching for new (and even innovative for a given company) sources of profits - arising, among others, as a result of lowering the costs of maintaining your own IT infrastructure and switching to, for example, cooperation on a cloud computing platform (see Kobyliński, 2010, p. 516 et seq.; Pazowski, 2014, pp. 82 et seq.; Skrzypek, 2014a, p. 2-7; Kryński, Miller, 2016, pp. 246 et seq.; Parlinska, Petrovska, 2017, pp. 310-316).

It is also important that the use of ICT may, over time, cause changes in the company's business model, which result from (Woźniak, Pawlak, Zaskórski, 2018, pp. 63-64):

- greater information integration of processes and organizational units, as well as moving away from the silo approach to process management towards integrated/ system management (Wysokińska-Senkus, 2013);

- supporting and facilitating the "implementation" of pro-innovative attitudes and behaviours among employees;

- increasing the level of consistency, usability, functionality, availability, completeness and comprehensiveness of the knowledge created in the enterprise, as well as better understanding and meeting the information needs of internal stakeholders and information integration of customer relationship management.

Of course, the above mentioned are only examples and basic effects related to the use of ICT in enterprises, which do not exhaust the entire spectrum of possible effects. It is also worth emphasizing that the use of ICT may be associated with the occurrence of various threats to enterprises - nevertheless, it is not discussed in this article. 


\section{Peculiarity of the NewConnect market}

The NewConnect market is an example of the so-called alternative market (Over The Counter - OTC). The subject of trading on alternative markets are securities and money market instruments. Currently, on alternative markets, apart from transactions on the currency market, futures contracts are also traded on stock indices, commodities, stocks, as well as CFDs and other financial instruments. Alternative markets offer investors interesting opportunities to allocate capital in various, primarily innovative and future-oriented industries (NewConnect, 2015; Woźniak, Pawlak, Zaskórski, 2018, p. 130).

Companies listed on alternative markets offer investors a potentially high return on investment, while at the same time increasing the risk of this investment. Moreover, investors are not sure how the market in which the companies operate will change, and whether the external effectiveness of the company's operations (i.e. the degree of adoption of this activity by external stakeholders, e.g. customers and cooperators) will be at the expected level i.e. high level (NewConnect, 2015).

The NewConnect market was established on August 30, 2007 on the Warsaw Stock Exchange (WSE). NewConnect equivalents are, for example, the EuroMTF market in Luxembourg, the AIM and SFM markets in Great Britain, and the Spanish Stock Exchange in Spain (NewConnect, 2015). NewConnect has the status of an organized market and is outside the regulated market by the WSE. Due to the specificity of issuers, this market offers more liberal formal requirements and disclosure obligations. Thus, it creates conditions for cheaper capital raising and development. The NewConnect market is perceived by companies as the beginning of their stock market "career" (NewConnect, 2018).

It is also worth noting that NewConnect (NewConnect, 2018, Woźniak, Pawlak, Zaskórski, 2018, p. 131):

- finances dynamic, development-oriented enterprises;

- has lower formal requirements than the regulated market;

- is characterized by low costs of companies' IPO and quotation of their shares;

- offers good exposure of companies to investors;

- is distinguished by the prestige and reputation of the market organizer, i.e. the Warsaw Stock Exchange;

- offers the promotion of listed companies and thus their recognition.

At this point, it should also be added that enterprises listed on the NewConnect market are mainly characterized by: small or medium size (these are mainly newly created enterprises, e.g. start-ups or enterprises in early stages of development, looking for effective ways to build their value on the market), high growth potential and flexibility/"agility", the desire to quickly raise capital for development, as well as difficulties in obtaining financing for development (NewConnect, 2015, p. 9 et seq.; Woźniak, Pawlak, Zaskórski, 2018, pp. 144-145). 


\section{Methodology of the research}

The subject of the empirical research is the use of ICT by companies listed on the NewConnect market. On the other hand, its goal is to identify the basic effects of using ICT in Polish enterprises conducting innovative activity (listed on the NewConnect market) in the area of improving information and decision-making processes. The respondents in the survey (CASI) were managers responsible for the IT area, relations with the environment or innovation, employed in companies listed on the NewConnect market. One respondent from each enterprise was included in the study. The criteria for selecting entities for the sample in the CASI study are presented in Table 1. The survey was conducted on a sample of 60 innovative companies listed on the NewConnect market (Woźniak, Pawlak, Zaskórski, 2018, p. 148).

Table 1. Selection of respondents to the research sample

\begin{tabular}{|c|c|}
\hline Components & \multicolumn{1}{c|}{ Description } \\
\hline $\begin{array}{c}\text { The criterion for } \\
\text { the selection of } \\
\text { entities }\end{array}$ & $\begin{array}{c}\text { Systematic random selection (including taking into account the criterion of the } \\
\text { leading profile of the company's activity indicated for the purposes of records on the } \\
\text { NewConnect market) in layers (the layers correspond to the size of the company) }\end{array}$ \\
\hline $\begin{array}{c}\text { Stakeholder groups } \\
\text { in a research }\end{array}$ & $\begin{array}{c}\text { 4 groups: internal stakeholders, institutional clients, individual clients, as well as } \\
\text { other entities, e.g. external process contractors, shareholders, cooperators, etc. }\end{array}$ \\
\hline Sample size & $\mathrm{N}=60$ enterprises based in Poland and operating in Poland \\
\hline
\end{tabular}

Source: Own elaboration based on: Woźniak, Pawlak, Zaskórski, 2018, p. 149

Table 2. Specification of the research sample $(\mathrm{N}=60)$

\begin{tabular}{|c|c|c|c|c|c|c|}
\hline \multirow{3}{*}{$\begin{array}{l}\text { Basic specification criteria of } \\
\text { research sample }\end{array}$} & \multicolumn{4}{|c|}{ The size of the enterprise } & & \\
\hline & \multicolumn{2}{|c|}{$\begin{array}{c}\text { Small } \\
\text { (10-49 workers) }\end{array}$} & \multicolumn{2}{|c|}{$\begin{array}{c}\text { Medium } \\
\text { and large } \\
(\geq 50 \text { workers })\end{array}$} & \multicolumn{2}{|c|}{ In total } \\
\hline & $\mathrm{N}$ & $\%$ & $\mathrm{~N}$ & $\%$ & $\mathrm{~N}$ & $\%$ \\
\hline \multicolumn{7}{|c|}{ Leading business profile - collective NewConnect classification } \\
\hline Trade & 7 & 12 & 4 & 7 & 11 & 18 \\
\hline $\begin{array}{l}\text { Services (IT, training activities, financial } \\
\text { services, eco-energy, recycling, media) }\end{array}$ & 21 & 35 & 9 & 15 & 30 & 50 \\
\hline Production/industrial processing & 9 & 15 & 10 & 17 & 19 & 32 \\
\hline \multicolumn{7}{|c|}{ The age of the enterprise } \\
\hline Less than 10 years & 13 & 22 & 3 & 5 & 16 & 27 \\
\hline $10-15$ years & 11 & 18 & 8 & 13 & 19 & 31 \\
\hline More than 15 years & 13 & 22 & 12 & 20 & 25 & 42 \\
\hline
\end{tabular}


cont. Tab. 2

\begin{tabular}{|c|c|c|c|c|c|c|}
\hline \multicolumn{7}{|c|}{ Scale of business activity (multiple choice question) } \\
\hline Local (1 city/commune/district) & 35 & 58 & 23 & 38 & 58 & 96 \\
\hline Regional (1-8 provinces in Poland) & 37 & 62 & 23 & 38 & 60 & 100 \\
\hline National (9-16 provinces in Poland) & 37 & 62 & 23 & 38 & 60 & 100 \\
\hline $\begin{array}{c}\text { European (at least 1 country in Europe } \\
\text { outside Poland) }\end{array}$ & 14 & 23 & 11 & 18 & 25 & 41 \\
\hline $\begin{array}{c}\text { International (at least 1 country in the world } \\
\text { outside Europe, including outside Poland) }\end{array}$ & 3 & 5 & 2 & 3 & 5 & 8 \\
\hline
\end{tabular}

Source: Own elaboration based on: Woźniak, Pawlak, Zaskórski, 2018, p. 155

Among all 60 enterprises, 11 entities at the time of the survey were engaged in trade, 30 entities provided various types of services, and 19 enterprises were active in the industrial processing sector. Small enterprises (10-49 employees) prevailed in the research sample. There were slightly fewer medium-sized or large enterprises - 23 entities. In terms of the age criterion, "old" enterprises, i.e. those operating on the market for over 15 years - 25 entities, dominated in the study. The smallest group were "young" enterprises, i.e. those operating on the market for less than 10 years there are 16 of them in the sample. Moreover, all the surveyed enterprises operated on a regional and national scale - 60 entities, while only 25 entities operated on a European scale and only 5 on the international scale (see Wereda, Woźniak, 2018; Woźniak, Pawlak, Zaskórski, 2018, pp. 154-155). The detailed specification of the test sample is included in Table 2.

\section{Data analysis and results}

The first of the analyzed areas of the occurrence of the effects of using ICT in companies from the NewConnect market is the management of information resources. In this case, it should be noted that, according to the respondents, the use of ICT has a strong or weak influence on the management of information resources in the surveyed enterprises. All of the listed effects of using ICT in the analyzed area of influence are characterized by such a situation - which is beneficial from the point of view of shaping the development of these enterprises and improving information and decision-making processes (Fig. 1). It is worth noting, however, that in the case of the factor related to "dissemination of data, information and knowledge to employees", one respondent indicated a weak negative impact. In addition, in the case of all the effects of using ICT listed in Fig. 1, respondents occasionally indicated no impact - however, the percentage of such responses is relatively small (it ranges from 3-13\%). 
In the case of the next area of the impact of the use of ICT, i.e. the use of information resources in the company's operations, the situation is similar to that in the first area (Fig. 1) - for all the outlined effects, strong and weak positive impact prevails (in the opinion of the respondents). Nevertheless, in this area (Fig. 2) there are relatively many respondents' indications regarding:

- no impact - this is especially true of the "creation of documentation" effect;

- weak negative impact - it is visible in the case of the following effects: "creation of documentation", and "creation of operating procedures and standards".

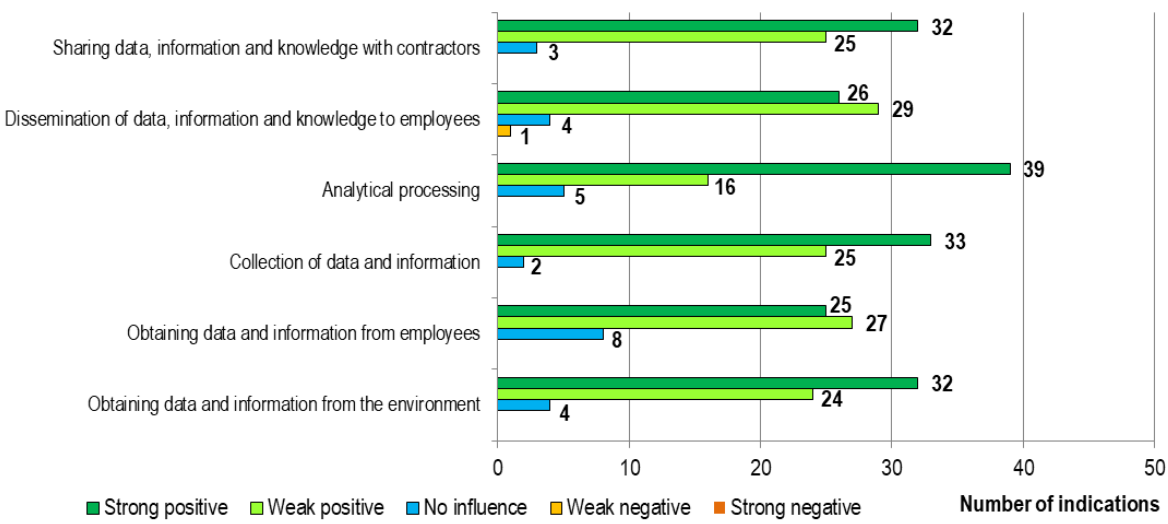

Fig. 1. Impact of ICTs' implementation on enterprise information resources management (information resources management area) $(\mathrm{N}=60)$

Source: Own elaboration

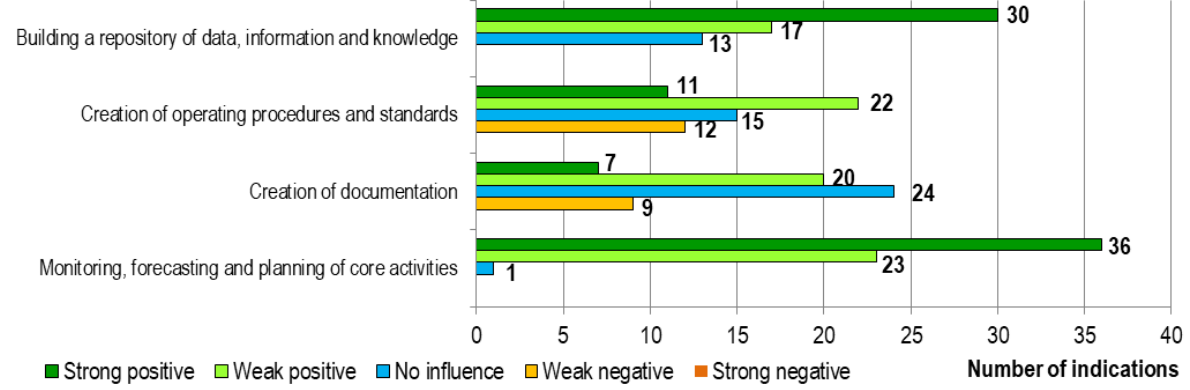

Fig. 2. Impact of ICTs' implementation on enterprise information resources management (area of the use of information resources in enterprises' activities) $(\mathrm{N}=60)$

Source: Own elaboration 
Table 3 presents the basic descriptive statistics for the effects related to the use of ICT in the management of information resources. It can be noticed here, among others, that all effects are characterized by a left-hand skew of the distribution - which is suggested by the fact that the majority of respondents gave answers (assessment of the effect occurrence on a 5-point scale) above the average value for all examined entities. The average values of the responses are also noteworthy - for all effects they are above 4 (for a 5-point scale), which is a very high level, proving that, on average, respondents assess the impact of using ICT on the management of information resources at a high level. On the other hand, the coefficient of variation is at a moderate level (from $11.6 \%$ to $18.8 \%$ - except for the effects: "creation of documentation" (26\%), and "creation of operating procedures and standards" (28.8\%) - which proves a relatively large dispersion of respondents' assessments - Tab. 3).

Table 3. Basic descriptive statistics for the impact of ICTs' implementation on enterprise information resources management $(\mathrm{N}=60)$

\begin{tabular}{|c|c|c|c|c|c|c|c|c|c|}
\hline \multirow[b]{2}{*}{$\begin{array}{l}\text { Elements of information } \\
\text { resources management }\end{array}$} & \multicolumn{9}{|c|}{ Basic descriptive statistics } \\
\hline & 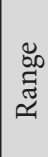 & 志 & 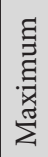 & 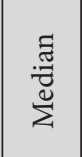 & 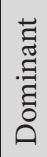 & $\stackrel{\varpi}{\Sigma}^{\approx}$ & 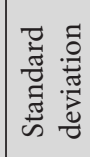 & 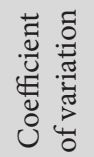 & 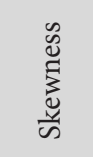 \\
\hline \multicolumn{10}{|c|}{ Area of the information resources management } \\
\hline $\begin{array}{c}\text { Obtaining data and information from the } \\
\text { environment }\end{array}$ & 2 & 3 & 5 & 5.00 & 5 & 4.47 & 0.623 & 0.139 & -0.738 \\
\hline $\begin{array}{c}\text { Obtaining data and information from } \\
\text { employees }\end{array}$ & 2 & 3 & 5 & 4.00 & 4 & 4.28 & 0.691 & 0.161 & -0.442 \\
\hline Collection of data and information & 2 & 3 & 5 & 5.00 & 5 & 4.52 & 0.567 & 0.125 & -0.644 \\
\hline Analytical processing & 2 & 3 & 5 & 5.00 & 5 & 4.57 & 0.647 & 0.142 & -1.225 \\
\hline $\begin{array}{l}\text { Dissemination of data, information } \\
\text { and knowledge to employees }\end{array}$ & 3 & 2 & 5 & 4.00 & 4 & 4.33 & 0.681 & 0.157 & -0.865 \\
\hline $\begin{array}{l}\text { Sharing data, information and knowledge } \\
\text { with contractors }\end{array}$ & 2 & 3 & 5 & 5.00 & 5 & 4.48 & 0.596 & 0.133 & -0.678 \\
\hline \multicolumn{10}{|c|}{ Area of the use of information resources in the activities of the enterprise } \\
\hline $\begin{array}{l}\text { Monitoring, forecasting and planning } \\
\text { of core activities }\end{array}$ & 2 & 3 & 5 & 5.00 & 5 & 4.58 & 0.530 & 0.116 & -0.698 \\
\hline Creation of documentation & 3 & 2 & 5 & 3.00 & 3 & 3.42 & 0.889 & 0.260 & 0.111 \\
\hline $\begin{array}{c}\text { Creation of operating procedures } \\
\text { and standards }\end{array}$ & 3 & 2 & 5 & 4.00 & 4 & 3.53 & 1.016 & 0.288 & -0.144 \\
\hline $\begin{array}{c}\text { Building a repository of data, information } \\
\text { and knowledge }\end{array}$ & 2 & 3 & 5 & 4.50 & 5 & 4.28 & 0.804 & 0.188 & -0.566 \\
\hline
\end{tabular}


Figure 3 presents an average value profile for respondents indications of the impact of ICTs implementation on enterprise information resources management - for the area of information resources management. It is worth noting here that the highest average scores of respondents in the sample of 60 enterprises are characterized by the effects of "analytical processing" (4.57), and "collection of data and information" (4.52). Nevertheless, the average ratings for all six effects are similar and high (the maximum rating is 5 ).

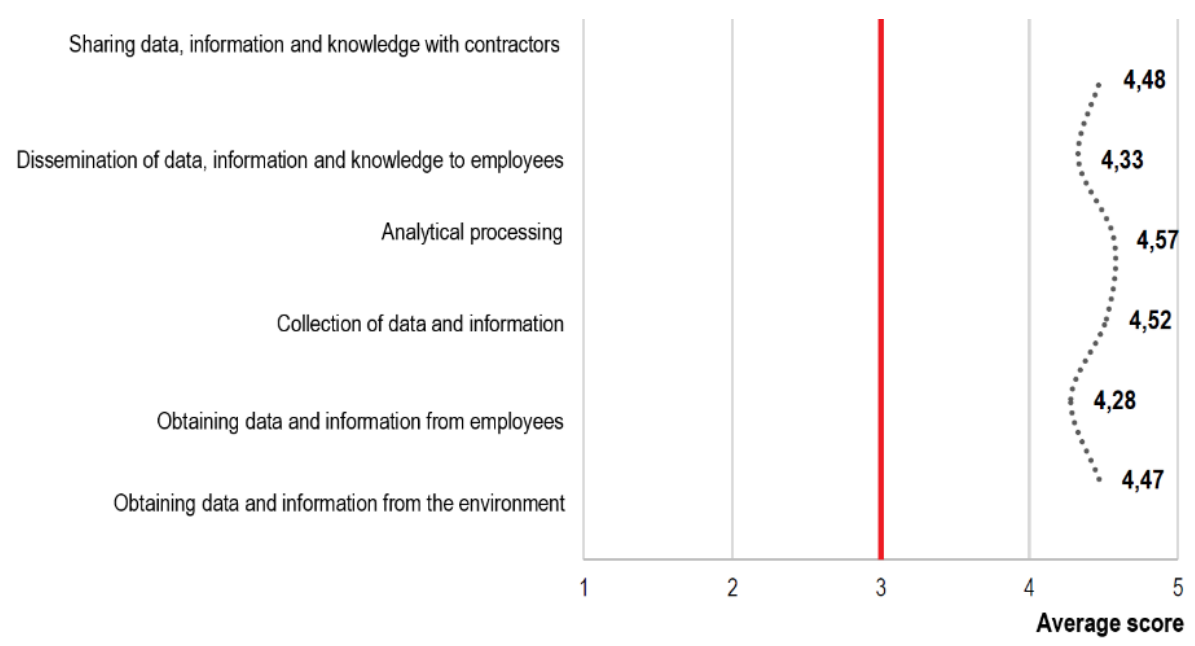

Fig. 3. Average value profile for respondents' indications of the impact of ICTs' implementation on enterprise information resource management (information resource management area) $(\mathrm{N}=60)$

Source: Own elaboration

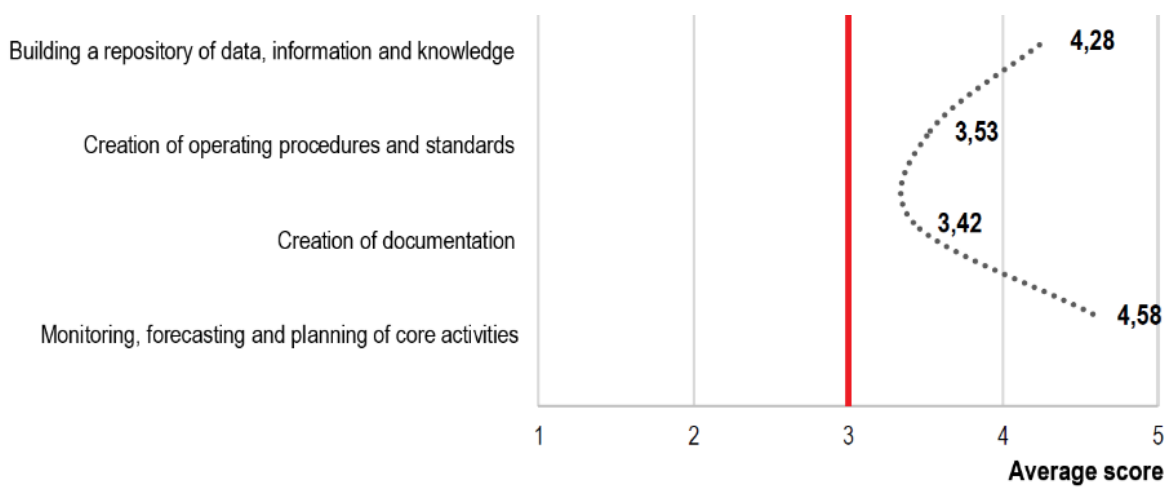

Fig. 4. Average value profile for respondents' indications of the impact of ICTs' implementation on enterprise information resource management (area of the use of information resources in enterprises' activities) $(\mathrm{N}=60)$

Source: Own elaboration 
On the other hand, Figure 4 presents an average value profile for respondents' indications of the impact of ICTs' implementation on enterprise information resources management - for the area of the use of information resources in enterprises' activities. In this case, the highest average marks have effects: "monitoring, forecasting and planning of core activities" (4.58), and "building a repository of data, information and knowledge" (4.28).

Another research area is the impact of ICT implementation on selected aspects of the development of the information resources acquisition and processing system in enterprises. In this case, it should be noted that respondents tend to indicate a very strong or strong influence of ICT use. This is the case with effects: "increase in the scope and level of processing towards active functions that support planning, forecasting and multi-cross-sectional data analysis", "increase in the scope of data, information and knowledge acquisition from the environment", as well as "increase in the scope of data, information and knowledge acquisition from employees" (Fig. 5). In the case of the effect of "creation of specialized organisational cells or positions related to the acquisition, processing and sharing of data, information and knowledge", the respondents most frequently pointed to the presence of a weak or unnoticeable impact of the use of ICT on the development of the information resources acquisition and processing system (in total 21 indications). In turn, the average impact of the use of ICT is most strongly observed in the case of the effect "increase in the scope and level of processing towards active functions that support planning, forecasting and multi-cross-sectional data analysis" (22 indications) (Fig. 5).

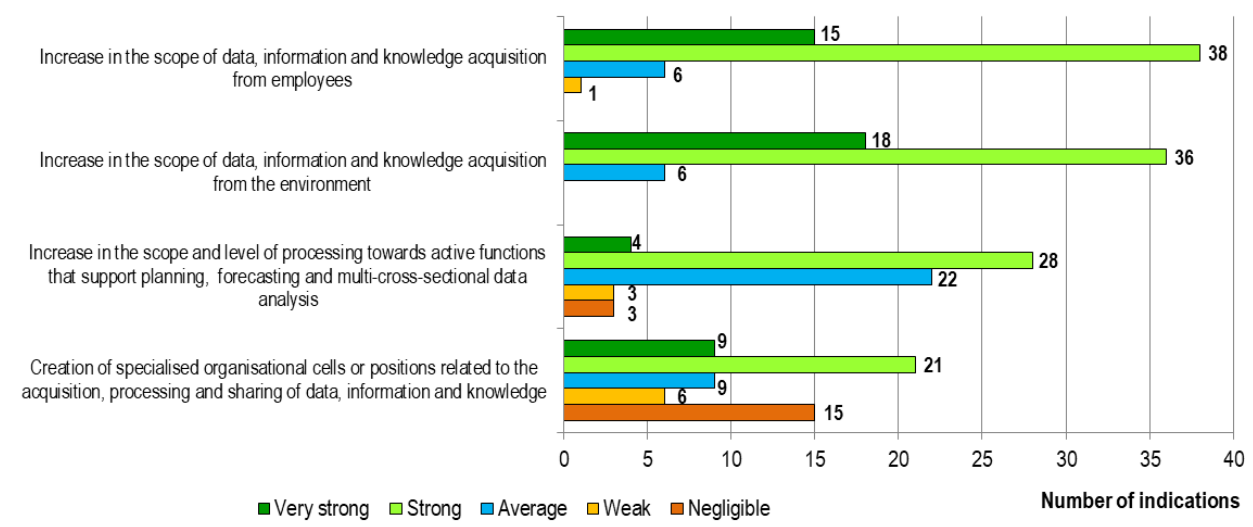

Fig. 5. Impact of ICTs' implementation on selected aspects of development of the system of the acquisition and processing of information resources in enterprises $(\mathrm{N}=60)$

Source: Own elaboration 
Table 4. Basic descriptive statistics of the impact of ICTs' implementation on selected aspects of development of the system of the acquisition and processing of information resources in enterprises $(\mathrm{N}=60)$

\begin{tabular}{|c|c|c|c|c|c|c|c|c|c|}
\hline \multirow[b]{2}{*}{ Selected aspects of system's development } & \multicolumn{9}{|c|}{ Basic descriptive statistics } \\
\hline & 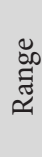 & 声 & 声 & 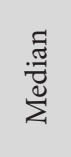 & 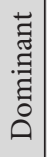 & $\stackrel{\Xi}{\Xi}$ & 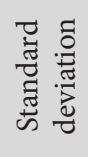 & 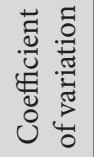 & 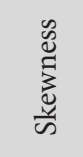 \\
\hline $\begin{array}{c}\text { Creation of specialised organisational cells } \\
\text { or positions related to the acquisition, pro- } \\
\text { cessing and sharing of data, information and } \\
\text { knowledge }\end{array}$ & 4 & 1 & 5 & 3.50 & 4 & 3.05 & 1.443 & 0.473 & 0.300 \\
\hline $\begin{array}{l}\text { Increase in the scope and level of processing } \\
\text { towards active functions that support plan- } \\
\text { ning, forecasting and multi-cross-sectional } \\
\text { data analysis }\end{array}$ & 4 & 1 & 5 & 4.00 & 4 & 3.45 & 0.891 & 0.258 & -0.885 \\
\hline $\begin{array}{l}\text { Increase in the scope of data, information } \\
\text { and knowledge acquisition from the envi- } \\
\text { ronment }\end{array}$ & 2 & 3 & 5 & 4.00 & 4 & 4.20 & 0.605 & 0.144 & -0.114 \\
\hline $\begin{array}{l}\text { Increase in the scope of data, information } \\
\text { and knowledge acquisition from employees }\end{array}$ & 3 & 2 & 5 & 4.00 & 4 & 4.12 & 0.640 & 0.155 & -0.505 \\
\hline
\end{tabular}

Source: Own elaboration

Table 4 contains basic descriptive statistics of the impact of ICTs' implementation on selected aspects of development of the system of the acquisition and processing of information resources in enterprises. It should be noted that all of the four specified effects of using ICT are characterized by a left-hand skew of distribution - which indicates that in the research sample, assessments of the impact of using ICT (on a 5 -point scale) above the average score predominate. The mean scores are also at a relatively high level (above the midpoint of the 5-point rating scale, i.e. the value of 3) (Fig. 6). In addition, the effect of "creation of specialized organisational cells or positions related to the acquisition, processing and sharing of data, information and knowledge" is characterized by a high coefficient of variation (47.3\%) - suggesting that the respondents differed significantly in their assessments for the importance of using ICT on the occurrence of this effect (Tab. 4).

Another area of analysis related to the impact of using ICT is improving the knowledge management system in enterprises. In this case, it should be noted that in the surveyed entities - in the opinion of the respondents - the use of ICT in a strong or weak positive way translates into the development of the following areas of knowledge: "efficiency of basic processes", "effectiveness of basic processes", "innovation processes", "marketing activities", as well as "market share" (Fig. 7). 
It is worth noting, however, that in the case of the area of knowledge related to "financial liquidity", the respondents primarily indicated the lack of impact of the use of ICT (38 responses). On the other hand, in the case of the "staff costs" area, the respondents assessed a weak negative impact of the use of ICT (19 indications) and no impact (21 indications) (Fig. 7).

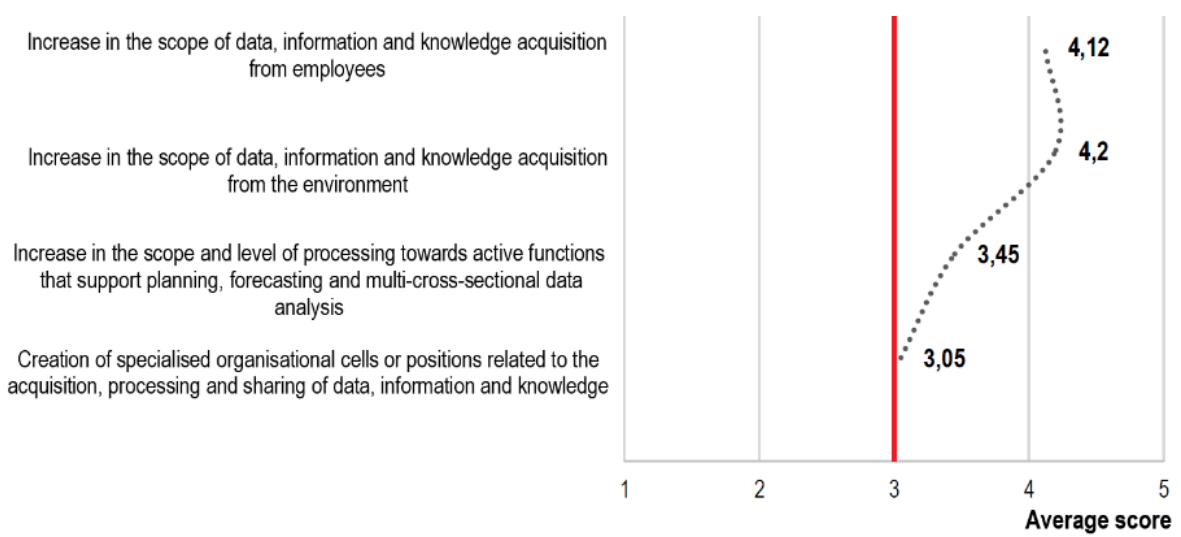

Fig. 6. Average value profile for respondents' indications of the impact of ICTs' implementation on selected aspects of development of the system of the acquisition and processing of information resources in enterprises $(\mathrm{N}=60)$

Source: Own elaboration

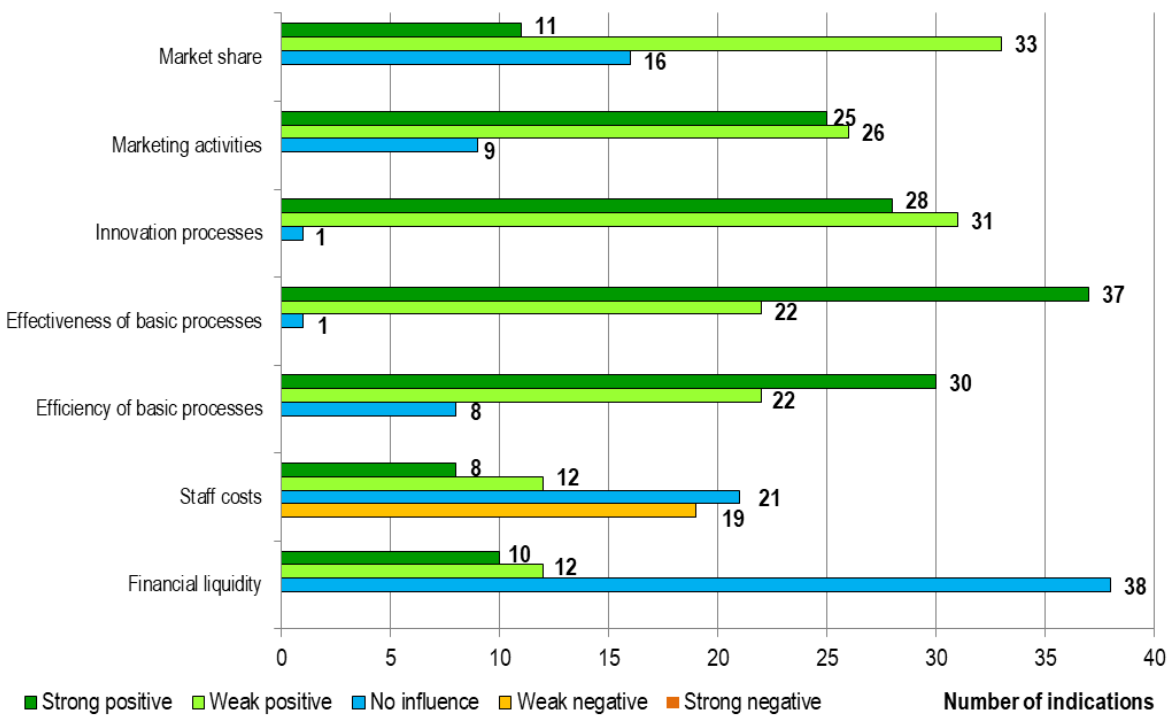

Fig. 7. Impact of ICTs' implementation on different areas of knowledge in the enterprise $(\mathrm{N}=60)$ Source: Own elaboration 
Table 5. Basic descriptive statistics for the impact of ICTs' implementation on different areas of knowledge in the enterprise $(\mathrm{N}=60)$

\begin{tabular}{|c|c|c|c|c|c|c|c|c|c|}
\hline \multirow[b]{2}{*}{ Knowledge areas in the enterprise } & \multicolumn{9}{|c|}{ Basic descriptive statistics } \\
\hline & 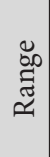 & 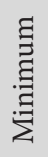 & 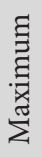 & 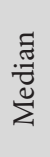 & 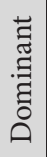 & $\stackrel{\text { ॠี }}{\stackrel{\Xi}{\Sigma}}$ & 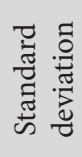 & 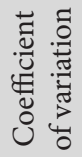 & 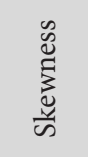 \\
\hline Financial liquidity & 2 & 3 & 5 & 3 & 3 & 3.53 & 0.769 & 0.218 & 1.039 \\
\hline Staff costs & 3 & 2 & 5 & 3 & 3 & 3.15 & 1.022 & 0.324 & 0.477 \\
\hline Efficiency of basic processes & 2 & 3 & 5 & 4,5 & 5 & 4.37 & 0.712 & 0.163 & -0.674 \\
\hline Effectiveness of basic processes & 2 & 3 & 5 & 5 & 5 & 4.6 & 0.527 & 0.115 & -0.775 \\
\hline Innovation processes & 2 & 3 & 5 & 4 & 4 & 4.45 & 0.534 & 0.120 & -0.14 \\
\hline Marketing activities & 2 & 3 & 5 & 4 & 4 & 4.27 & 0.71 & 0.166 & -0.437 \\
\hline Market share & 2 & 3 & 5 & 4 & 4 & 3.92 & 0.671 & 0.171 & 0.097 \\
\hline
\end{tabular}

Source: Own elaboration

The distribution of respondents' ratings for the areas of knowledge: "financial liquidity" and "staff costs" is characterized by a right-hand skew - which means that respondents more often indicated a lower rating (on a 5-point scale) than the average rating for the research sample. On the other hand, left-hand skewness was observed for the five remaining areas of knowledge (Tab. 5). The average respondents' scores for all areas of knowledge are relatively high (above the middle value for the rating scale, i.e. value 3) (Fig. 8). Moreover, the respondents' assessments of the impact of using ICT on the development of selected areas of knowledge are characterized by moderate values of the coefficient of variation (from 11.5 to $32.4 \%$ ) (Tab. 5).

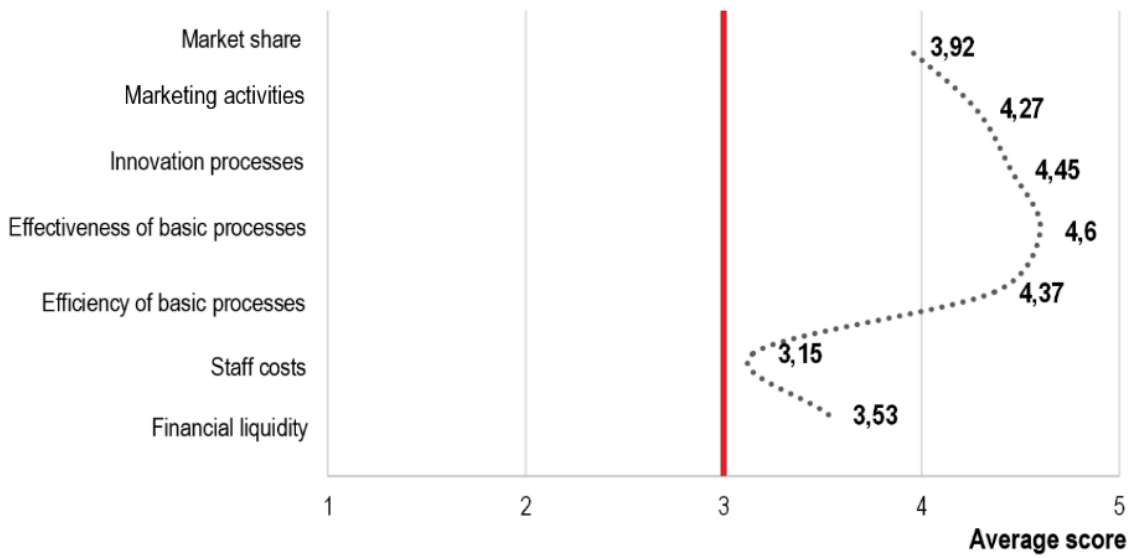

Fig. 8. Average value profile for respondents' indications of the impact of ICTs' implementation on different areas of knowledge in the enterprise $(\mathrm{N}=60)$ 
Another area of analysis is the impact of the use of ICT on improving the knowledge management system in the enterprise. For the effects: "enhancing competences (e.g. knowledge and skills) of employees", and "increasing the need for training", the dominance of a very strong or strong influence of the use of ICT can be observed. On the other hand, in the case of the "bridging the gap in the access to key knowledge for lower-level workers" effect, assessments at the level of low or no impact of ICT use dominate. On the other hand, for the effect of "making data, information and knowledge collected more relevant to current job's information needs", the responses of respondents suggesting an average impact of the use of ICT prevail (Fig. 9).

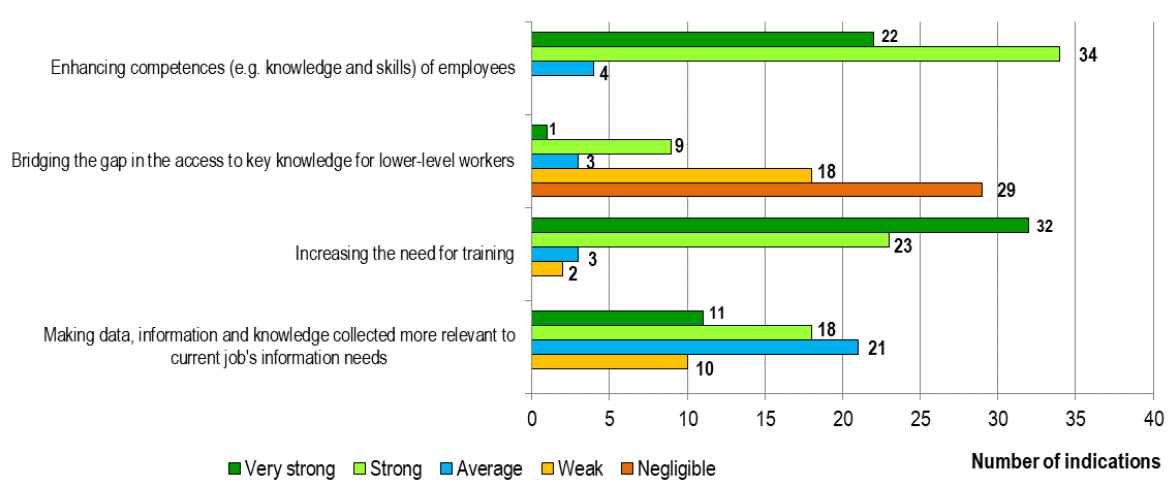

Fig. 9. Impact of ICTs' implementation on selected aspects of improving the knowledge management system in the enterprise $(\mathrm{N}=60)$

Source: Own elaboration

For the two effects "making data, information and knowledge collected more relevant to current job's information needs", and "bridging the gap in the access to key knowledge for lower-level workers" one can observe the right-hand skewness of the distribution, and for the effects "increasing the need for training", and "enhancing competences (e.g. knowledge and skills) of employees" - left-hand skewness (Tab. 6). The average respondents' scores for the three effects of using ICT are relatively high (above the middle value for the rating scale, i.e. value 3). On the other hand, for the effect of "bridging the gap in the access to key knowledge for lower-level workers", the average ocean of respondents is at a very low level (on a 5-point scale) and amounts to 1.92 (Fig. 10). Moreover, the respondents' assessments of the impact of using ICT on improving the knowledge management system in the enterprise are characterized by moderate values of the coefficient of variation (from 13.7 to $28.1 \%)$. Only for the effect of "bridging the gap in the access to key knowledge for lower-level workers" the coefficient of variation is high (59.3\%) (Tab. 6). 
Table 6. Basic descriptive statistics of the impact of ICTs' implementation on selected aspects of improving the knowledge management system in the enterprise $(\mathrm{N}=60)$

\begin{tabular}{|c|c|c|c|c|c|c|c|c|c|}
\hline \multirow[b]{2}{*}{ Selected aspects of system's improvement } & \multicolumn{9}{|c|}{ Basic descriptive statistics } \\
\hline & $\begin{array}{l}\mathscr{\infty}_{0} \\
\widetilde{\Xi} \\
\tilde{\simeq}\end{array}$ & 主 & 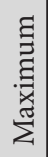 & 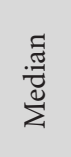 & 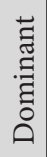 & $\stackrel{\Xi}{\check{\Sigma}}$ & 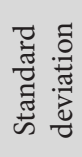 & 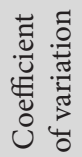 & 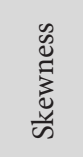 \\
\hline $\begin{array}{l}\text { Making data, information and knowledge } \\
\text { collected more relevant to current job's } \\
\text { information needs }\end{array}$ & 3 & 2 & 5 & 3.00 & 3 & 3.50 & 0.983 & 0.281 & 0.055 \\
\hline Increasing the need for training & 3 & 2 & 5 & 5.00 & 5 & 4.42 & 0.743 & 0.168 & -1.370 \\
\hline $\begin{array}{c}\text { Bridging the gap in the access to key knowledge } \\
\text { for lower-level workers }\end{array}$ & 4 & 1 & 5 & 2.00 & 1 & 1.92 & 1.139 & 0.593 & 1.093 \\
\hline $\begin{array}{l}\text { Enhancing competences (e.g. knowledge and } \\
\text { skills) of employees }\end{array}$ & 2 & 3 & 5 & 4.00 & 4 & 4.30 & 0.591 & 0.137 & -0.184 \\
\hline
\end{tabular}

Source: Own elaboration

Enhancing competences (e.g. knowledge and skills) of employees

Bridging the gap in the access to key knowledge for lower-level workers

Increasing the need for training

Making data, information and knowledge collected more relevant to current job's information needs

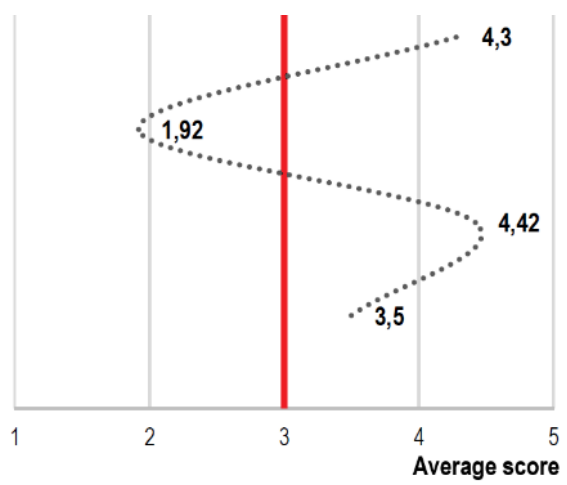

Fig. 10. Average value profile for respondents' indications of the impact of ICTs' implementation on selected aspects of improving the knowledge management system in the enterprise $(\mathrm{N}=60)$

Source: Own elaboration

The last analyzed area of ICT influence on the activities of innovative enterprises is the effectiveness of communication processes with stakeholders. In this case, it should be noted that for effects: "increase in the level of responsibility of managers for issuing commands, achieving team goals, and building relationships with stakeholders", and "increase in the level of responsibility of non-managers for the performance of tasks, and building relationships with stakeholders" is dominated by 
the respondents' assessment indicating the average impact of the use of ICT. For the effect of "increase in the level of virtualization of work (in teams)", the weak impact of ICT use is weighed, and for the effect of "introducing conscious restrictions on access to data, information and knowledge for different management positions and levels", assessments at the level of impact dominate weak or negligible (none). In the case of the "introduction of electronic document workflow policies" effect, both the strong and the medium impact are highly exposed by the respondents - with a slight impact at the weak level (Fig. 11).

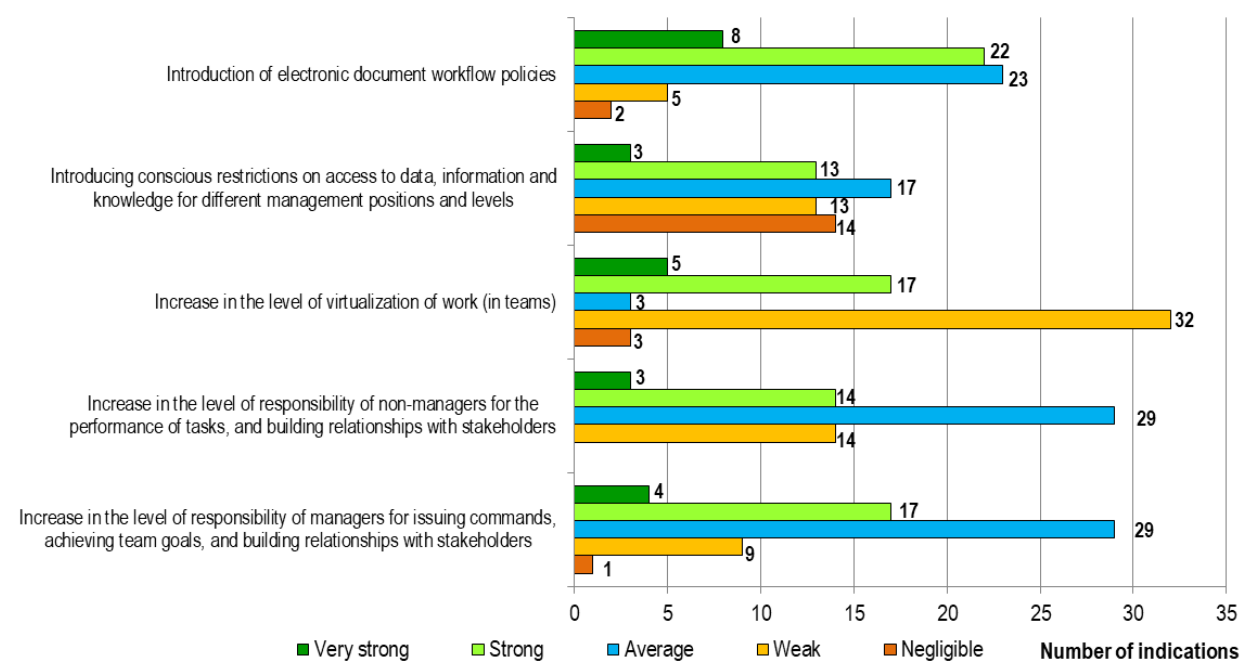

Fig. 11. Impact of ICTs' implementation on selected aspects of the increase of efficiency of communication processes with stakeholders $(\mathrm{N}=60)$

Source: Own elaboration

Out of all six analyzed effects, only one is left-skewed - it is "introduction of electronic document workflow policies". Moreover, all effects are characterized by a relatively high level of the coefficient of variation (from $26.3 \%$ to $45.9 \%$ ) (Tab. 7).

The average respondents' scores for the three effects of ICT use are relatively high (above the middle value for the rating scale, i.e. 3). On the other hand, for the effects: "increase in the level of virtualization of work (in teams)", and "introducing conscious restrictions on access to data, information and knowledge for different management positions and levels", the average ocean of respondents is at a relatively low level (in 5-point scale) and is 2.82 and 2.63, respectively (Fig. 12). 
Table 7. Basic descriptive statistics of the impact of ICTs' implementation on selected aspects of the increase of efficiency of communication processes with stakeholders $(\mathrm{N}=60)$

\begin{tabular}{|c|c|c|c|c|c|c|c|c|c|}
\hline \multirow[b]{2}{*}{ Selected aspects of efficiency improvement } & \multicolumn{9}{|c|}{ Basic descriptive statistics } \\
\hline & 品 & 志 & 范 & 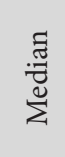 & 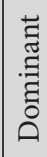 & $\sum_{\Sigma}^{\Xi}$ & 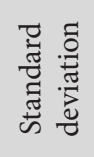 & 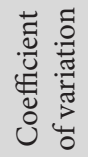 & 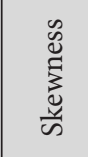 \\
\hline $\begin{array}{l}\text { Increase in the level of responsibility of ma- } \\
\text { nagers for issuing commands, achieving team } \\
\text { goals, and building relationships with stake- } \\
\text { holders }\end{array}$ & 4 & 1 & 5 & 3.00 & 3 & 3.23 & 0.851 & 0.263 & 0.038 \\
\hline $\begin{array}{l}\text { Increase in the level of responsibility of non- } \\
\text { managers for the performance of tasks, and } \\
\text { building relationships with stakeholders }\end{array}$ & 3 & 2 & 5 & 3.00 & 3 & 3.10 & 0.817 & 0.264 & 0.389 \\
\hline $\begin{array}{l}\text { Increase in the level of virtualization of work } \\
\text { (in teams) }\end{array}$ & 4 & 1 & 5 & 2.00 & 2 & 2.82 & 1.157 & 0.410 & 0.507 \\
\hline $\begin{array}{l}\text { Introducing conscious restrictions on access } \\
\text { to data, information and knowledge for dif- } \\
\text { ferent management positions and levels }\end{array}$ & 4 & 1 & 5 & 3.00 & 3 & 2.63 & 1.207 & 0.459 & 0.095 \\
\hline $\begin{array}{l}\text { Introduction of electronic document work- } \\
\text { flow policies }\end{array}$ & 4 & 1 & 5 & 3.50 & 3 & 3.48 & 0.948 & 0.272 & -0.383 \\
\hline
\end{tabular}

Source: Own elaboration

Introduction of electronic document workflow policies

Introducing conscious restrictions on access to data, information and knowledge for different management positions and levels

Increase in the level of virtualization of work (in teams)

Increase in the level of responsibility of non-managers for the performance of tasks, and building relationships with stakeholders

Increase in the level of responsibility of managers for issuing commands achieving team goals, and building relationships with stakeholders

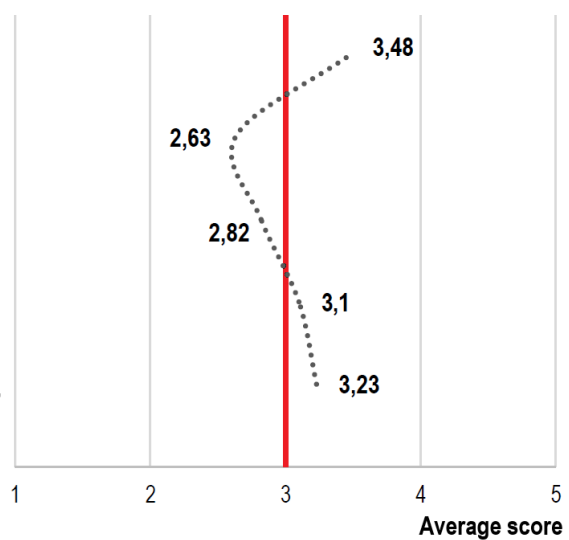

Fig. 12. Average value profile for respondents' indications of the impact of ICTs' implementation on selected aspects of the increase of efficiency of communication processes with stakeholders $(\mathrm{N}=60)$ 


\section{Conclusions}

The conducted research indicates that in the analyzed innovative entities, the use of ICT has a greater importance and a greater impact on the general processes of information resource management, but less importance and impact on the improvement of the use of information resources in the company's operations. This shows that the surveyed companies focus on simple functions of ICT and their simple application. Advanced functions related to supporting the development of the entire enterprise are usually not used or their role and importance are not noticed.

The obtained data also shows that in the examined ICT entities they mainly influence the improvement of the processes of acquiring and processing information resources) - thus, the process aspect of the information resources management system is exposed. On the other hand, the structural aspect (creating and improving organizational structures related to the management of information resources) is less often noticed by the respondents. This situation is evidenced by the fact that respondents are inclined to use simple functions of ICT, but do not integrate these technologies with the organizational structure (and its evolution) of their enterprise.

The study also shows the fact that in the examined innovative enterprises the use of ICT influences mainly the market and product aspect. This may result from the specificity of the activities of these entities, as most investments as well as organizational and resource potential are directed to strengthening the market position and creating value for stakeholders (mainly external).

The conducted research shows that, in the opinion of the respondents, the use of ICT has the greatest impact on the area of employee competence development. A weaker impact is observed by the respondents in the case of activities related to "adjusting" the knowledge management system to the specificity of changes taking place in the structure of the surveyed enterprises.

Moreover, the obtained data show that the respondents perceive the influence of ICT primarily on the area of document circulation and increasing employee responsibility. This is a favourable situation, because the use of ICT is related to the improvement of information and decision-making processes and the involvement of employees at various levels of management in achieving the company's goals and shaping relations with stakeholders. It is particularly important from the perspective of the implementation of innovative processes, because it integrates internal stakeholders, as well as the company with external entities. In turn, the use of ICT, in the opinion of the respondents, has a lower impact on the implementation of the assumptions of information asymmetry - which is beneficial from the point of view of the implementation of innovative projects in accordance with the "open model". 


\section{REFERENCES}

[1] Adamska-Chudzińska, M., 2014. Konkurencyjność przedsiębiorstwa oparta na wartości relacji z interesariuszami, Nierówności Społeczne a Wzrost Gospodarczy, No. 37.

[2] Gapinski, A.J., 2016. Cloud Computing Services - Status and Trends, e-mentor, No. 2.

[3] Grudzewski, W.M. et al., 2010. Sustainability w biznesie, czyli przedsiębiorstwo przyszłości. Zmiany paradygmatów i koncepcji zarządzania, Warszawa: Poltext.

[4] Kobyliński, A., 2010. Fenomen Cloud Computingu, Zeszyty Naukowe Uniwersytetu Szczecińskiego. Ekonomiczne Problemy Usług, No. 58.

[5] Korpus, J., 2016. Zasoby niematerialne w optyce strategicznych pól konkurowania. In: Poniatowska-Jaksch, M. (Ed.), Strategiczne pola konkurowania, Warszawa: Szkoła Główna Handlowa.

[6] Konzyński, P., 2018. Przywództwo w erze cyfrowej. Sposoby pokonywania ograniczeń na platformach społecznościowych, Warszawa: Poltext.

[7] Krok, E., 2016. Cloud computing w zarządzaniu organizacją, Studia Informatica Pomerania, No. 1(39).

[8] Квок, E., 2017. Chmura obliczeniowa w przedsiębiorstwie, Organizacja i Zarządzanie, No. 1(37).

[9] Krý́ski, M., Miller, P., 2016. Cloud computing - szansa i ryzyko dla firmy, Ekonomiczne Problemy Ustug, No. 123.

[10] LARose, D.T., 2006. Odkrywanie wiedzy z danych. Wprowadzenie do eksploracji danych, Warszawa: Wydawnictwo Naukowe PWN.

[11] Mrówka, R., 2013. Organizacja hiperarchiczna. Czynniki kreujące. Geneza modelu. Zarzadzanie, Warszawa: Szkoła Główna Handlowa.

[12] NewConnect, 2015. Raport o rynku NewConnect 2015. Podsumowanie funkcjonowania pierwszej alternatywnej platformy obrotu $w$ Polsce, https://www.gpw.pl/pub/files/PDF/2015-05-25_NEWCONNECTraport2015.PDF (12.05.2016).

[13] NewConnect, 2018. https://newconnect.pl/o-rynku (03.09.2018).

[14] NowickA, K., 2014. Cloud computing - możliwości zastosowania w nowym modelu biznesowym, Gospodarka Materiałowa i Logistyka, No. 7 (CD).

[15] Nowicka, K., 2016. Cloud computing w zarządzaniu relacjami z interesariuszami, Przedsiębiorczość i Zarządzanie, No. 17(12), part 1.

[16] Oleksyn, T., 2013. Zamiast zakończenia. Wyzwania w szerszej skali. In: Oleksyn, T. (Ed.), Filozofia a zarzadzanie, Warszawa: Wolters Kluwer.

[17] Orzechowski, R., 2008. Budowanie wartości przedsiębiorstwa $z$ wykorzystaniem IT, Warszawa: Szkoła Główna Handlowa.

[18] Parlinska, M., Petrovska, I., 2017. Cloud Computing and Its Benefits, Information Systems in Management, No. 4.

[19] Pazowski, P., 2014. Ekonomiczne aspekty wdrożenia modelu cloud computing, Modern Management Review, No. 21(2).

[20] Rynio, D., 2010. Podstawy budowy gospodarki opartej na wiedzy i innowacjach w UE w warunkach gospodarki globalnej, Prace Naukowe Uniwersytetu Ekonomicznego we Wrocławiu, No. 132.

[21] SARnecka, J., 2006. Nowoczesna komunikacja w organizacji, Zeszyty Naukowe Uniwersytetu Szczecińskiego. Studia Informatica, No. 18.

[22] Skrzy pek, A., 2014a. Model cloud computing szansą na rozwój organizacji, Problemy Jakości, No. 3.

[23] Skrzypek, E., 2014b. Zarządzanie wiedzą jako wymóg współczesności, Problemy Jakości, No 2. 
[24] SzMajSer, R., 2018. Determinanty rentowności firm działajacych w sektorze nowoczesnych usług biznesowych, Warszawa: Difin.

[25] Wereda, W., WoźNiak, J., 2017. Risk in building the intelligent organization model. In: Pînzaru, F., Zbuchea, A., Brătianu, C., Vătămănescu, E.M., Mitan, A. (Eds.), Shift! Major challenges of today's economy, Bucharest: Tritonic.

[26] Wereda, W., WoźNIAK, J., 2018. Way to Organizational Excellence of Innovative Enterprises Through the Communication with Stakeholders, 6th International Conference STRATEGICA 2018: Challenging the Status Quo in Management and Economics, College of Management, National University of Political Studies and Public Administration, Bucharest, Romania, 11-12 October 2018.

[27] Woźniak, J., Pawlak, K., Zaskórski, P., 2018. Technologie teleinformatyczne w gospodarce informacyjnej i komunikowaniu się współczesnych przedsiębiorstw: perspektywa rynku NewConnect, Warszawa: Wojskowa Akademia Techniczna.

[28] Wysokińska-Senkus, A., 2013. Doskonalenie systemowego zarządzania w kontekście sustainability, Warszawa: Difin.

[29] ZAskórski, P., 2012. Asymetria informacyjna w zarządzaniu procesami, Warszawa: Wojskowa Akademia Techniczna.

[30] ZióŁKowska, B., Karbownik, K., 2018. Nowoczesne technologie informacyjno-komunikacyjne wykorzystywane w zarządzaniu telepracą, Studia i Prace WNEiZ US, No. 52/2.

[31] Żur, A., 2005. Komunikacja w organizacji opartej na wiedzy, Zeszyty Naukowe. Akademia Ekonomiczna w Krakowie, No. 671. 
